\title{
The Akashic Records: Origins and Relation to Western Concepts
}

\author{
Alex Nash
}

https://doi.org/10.14712/25704893.2020.3

\begin{abstract}
The term Akashic Records originates from the Indian word Akasha, which gained a new meaning after its adoption by the Theosophical Society. The first part of the text explains the origin of the concept of both Akasha and the Akashic Records. The article argues that the transformation was influenced by elements from philosophy and physics, as well as by the Christian doctrine of predestination. The final part of the article then describes an example of how concepts similar to the Akashic Records still appeared in the 20th century.
\end{abstract}

Keywords: Akashic records; Theosophy; Quantum physics; Predestination; Philosophy

\begin{abstract}
Abstrakt: Termín „akašické“ záznamy pochází z indického pojmu Akasha, který po přijetí Theosofickou společností získal nový význam. Úvodní část textu vysvětluje původ obou těchto termínů. Článek argumentuje, že tato proměna byla ovlivněna prvky filozofie, fyziky i křestanskou naukou predestinace. Druhá část článku pak poskytuje př́klady využití konceptů podobných akášickým záznamům i ve dvacátém století.
\end{abstract}

Klíčová slova: Akášické záznamy; theosofie; kvantová fyzika; predestinace; filosofie

Received: 11 November 2019, Accepted: 7 January 2020

Published online: 2 October 2020

Alex Nash, Hussite Theological Faculty, Charles University

E-mail: regentus@seznam.cz

(C) 2020 The Author. This is an open-access article distributed under the terms of the Creative

Commons Attribution License (http://creativecommons.org/licenses/by/4.0). 
Akashic Records is a concept describing a space that contains information about everything in existence since the dawn of time. ${ }^{1}$ If one were able to peer through the layer of reality separating us from it and access this infinite database, they would essentially be able to attain absolute knowledge on a scale that surpasses anything a normal human mind can comprehend by far.

In our digital age, with wi-fi networks always surrounding us, one might even be tempted to call these records the Internet of the universe. Yet at the same time, these archives are not meant to be seen as merely an abstract metaphysical concept, but instead they are to be an integral part of existence itself. They are a subtle part of life; one that has been and always will be present, regardless of our awareness of it.

However, the concept of the Akashic Records as we understand them today is only a result of a long process of transformation that arguably started with the rise of the Theosophical Society and its adoption of many native Indian terms. This includes the term Akasha, from which the Akashic Records would be derived.

The aim of this article is to explore the origins of Akasha and then explore possible influences on the progression from Akasha to the Akashic Records by looking for similar themes or concepts (such as parallel dimensions, the ability to reach omniscience, or predestination) in both science and religion. The article argues that there was a significant external influence, present in the transformation from Akasha to the Akashic Records, which can be at least partially understood through comparing each selected field of interest with the concept of the Akashic Records.

\section{The origins of the term Akasha}

The origin of the term Akasha (Sanskrit Ākāśa) is in itself surprisingly difficult to pinpoint, mainly because of the enormous amount of esoteric and occult lore that has been attached to it since the beginning of the nineteenth century. Because of that, it is difficult to tell where the original concept ends, and its Western incarnation begins.

In all probability, Akasha comes from a transliteration of the Sanskrit word Ākāśa by early Western Indologists. At its core, Ākāśa can be translated as space, atmosphere or sky. Depending on the context it can also take a number of other meanings. ${ }^{2}$

In the complex metaphysical system of Samkhyana for example, Ākāśa is one of the five gross elements (mahābhütas), possessing a creative quality the other four lack. At times it is even considered responsible for the creation of the others. It is worth noting that it was from this particular version that Swami Vivekananda (1863-1902) drew inspiration when he presented the term to Western audiences for the first time in his Raja Yoga (1896), although his own version presents Ākāśa as one of only two

\footnotetext{
"Akashic record" [online], https://www.britannica.com, 2015, accessed January 2020, available online at https://www.britannica.com/topic/Akashic-record\#ref260257.

2 Anna Pokazanyeva, "Mind Within Matter: Science, The Occult, and the (Meta)Physics of Ether and Akasha”, Zygon 51 (2, 2016): p. 325-326.
} 
materials that make up the known universe - the other being Prāna ${ }^{3}$. On the other hand, in the Nyāya-Vaiśeșika School, the term is generally understood as being a substratum of sound. ${ }^{4}$

At the same time, Jainism and Buddhism also have their own meanings for the term. Within Jainism, it is seen as one of the six major substances (dravyas), while also providing a foundation on which the other five substances (namely jiva, pudgala, dharma, adharma and $k \bar{a} l a$ ) exist. There are also two recognized types of Ākāśa: Lokakasha and Alokakasha, with the former designating a space containing all matter and motion, whereas the latter consists of an infinite void. ${ }^{5}$

In a somewhat similar fashion, Buddhism recognizes two types of Ākāśa. The first describes a limited space (named $\bar{a} k \bar{a} s a-d h \bar{a} t u$ ), which was defined by Nyanatiloka Mahathera (1878-1957) in the following way:

The space element has the characteristic of delimiting matter. Its function is to indicate the boundaries of matter. It is manifested as the confines of matter; or its manifestation consists in being untouched (by the 4 great elements), and in holes and apertures. Its proximate cause is the matter delimited. It is on account of the space element that one can say of material things delimited that "this is above. Below, around that."

The second, representing an endless empty space that has no place in objective reality (being purely conceptual), is named ajatākās $\bar{a}$ and it is not included in the triad of the wholesome (kusalatika), which comprise reality. Later Buddhist schools changed the concept to serve as one of the unconditioned or uncreated states (asankhata dharma) instead, although not all schools adopted or supported this version.

It should be mentioned, however, that the previous definitions should not be taken as absolute, since the author's conversion to Buddhism was greatly influenced by the Theosophical lecturer Edwin Böhme. ${ }^{7}$

The problem with any unified definition of Ākāsa is that the usage and understanding of the term is highly inconsistent and later Indian philosophers and scholars had different views on it. Some of these thinkers, like the 16th century scholar Vijnānabhikṣu, even proposed the existence of several different types of Ākāśa. Due to this lack of a clear definition, Ākāśa remained only an obscure concept, as far as Indian philosophy was concerned. ${ }^{8}$

To find a Western equivalent to Ākāśa, the closest match would be aether (aïńp), the so called fifth element of the world, originally proposed by Aristotle and then

\footnotetext{
Swami Vivekananda, Raja Yoga, Leeds: Celepha’s Press 2003, p. 26.

A. Pablo Iannone, Dictionary of World Philosophy, New York: Taylor \& Francis 2001, p. 30.

5 Pravin K. Shah, "Six Universal Substances or Entities" [online], Jain Study Center of North Carolina, 2002, accessed May 2019, available at https://sites.fas.harvard.edu/ pluralsm/affiliates /jainism/jainedu/6dravya.htm.

6 Nyantiloka, Buddhist Dictionary, Kandy: Buddhist Publication Society 1998, p. 24-25.

7 Bhikku Nyanatusita and Hellmuth Hecker, The Life of Nyanatolika Thera: The Biography of a Western Buddhist Pioneer, Kandy: Buddhist Publication Society 2008, p. 19-20.

8 Pokazanyeva, Mind Within Matter, p. 320.
} 
reintroduced to the world by René Descartes (1596-1650) in the 17th century ${ }^{9}$. Although the scientific community has long since disavowed the concept, it is worth noting that in the nineteenth century aether was a valid hypothesis in physics, seen as a medium for gravitational and electromagnetic forces in the world.

Similarly to Ākāśa, the term aether was adopted by the Theosophical Society and gained a new meaning, transforming from a medium for propagating light into a human aura that is visible to those with sufficient clairvoyance. ${ }^{10}$ As such, it bears notable similarities with Kosha (Sanskrit kósa), the coverings of the Atman from Vedantic philosophy. ${ }^{11}$ Given the efforts to replace original Indian terms with their Western equivalents, such as the aforementioned Kosh $a$ with the term Etheric body, ${ }^{12}$ this might have been a conscious effort on the organization's part to grant greater legitimacy to their own terms.

When compared to the older form of $\bar{A} k \bar{a} s$ a, which denoted space, the term $A k a$ sha at that time lacked its archival function that is nowadays seen as its main feature. This changed with the rise of the Theosophical Society in 1875 and their subsequent efforts in bringing Indian concepts and ideas to the West.

It is up to debate whether the conversion of Ākāśa into the modern Akasha was initiated by Helena Petrovna Blavatsky (1831-1891) herself or one of her contemporaries. The term certainly came up in her work, but it was still not in the form of a cosmic archive. Instead, it seemed to be the source of all existence, a sort of primordial element that bore some similarities to Vivekananda's own concept of Ākāśa. To quote:

For the Occultist "Space" and "Universe" are synonyms. In Space there is not Matter, Force, nor Spirit, but all that and much more. It is the One Element, and that one the Anima Mundi - Space, Ãkâsha, Astral Light - the Root of Life which, in its eternal, ceaseless motion, like the out-and in-breathing of one boundless ocean, evolves but to reabsorb all that lives and feels and thinks and has its being in it. ${ }^{13}$

Considering the radical change of meaning accompanying the conversion of Ākāśa into Akasha, however, it is obvious that the members of the Theosophical Society took great liberties with the original term and imbued it with a meaning it had not possessed before. In the perspective of at least some members of the society, however, they were merely repeating the truth that had already been present elsewhere.

\footnotetext{
${ }^{9}$ Stephen Gaukroger, René Descartes: The World and Other Writings, Cambridge: Cambridge University Press 2004, p. 11

${ }^{10}$ Rudolf Steiner, An Outline of Occult Science, London: Rudolf Steiner Press 1909, p. 196-197.

11 "Kosha” [online] https://www.yogapedia.com/, accessed January 2020, available online at https:// www.yogapedia.com/definition/5307/kosha.

12 "Man Visible and Invisible" [online] https://www.anandgholap.net/index.html, 2016, accessed January 2020, available online at https://www.anandgholap.net/Man_Visible_And_Invisible-CWL .htm.

${ }^{13}$ Helena Petrovna Blavatsky, The Secret Doctrine, vol. 3, London: Theosophical Publishing Company 1888, p. 314.
} 
An example is The Buddhist Catechism (1881), written by Henry Steel Olcott (18321907). As he was the co-founder of the Theosophical organization, it is clear that his words would be received with a measure of respect among his fellow members. Although his focus was primarily on Buddhism (to the point of being one of the most renowned converts of his century), it is certain that others within the society were at least aware of his usage of the term. To quote:

Early Buddhism then clearly held to a permanency of records in the Ākāsha, and the potential capacity of man to read the same when he has evolved to the stage of true individual enlightenment. ${ }^{14}$

The notion of the Akashic Records can already be traced in his text, including the option of a sufficiently enlightened individual reaching and accessing their content. The concept appears in his work twice more; in both cases as an explanation of a selected part of Buddhist teaching.

Q. Do Buddhists accept the theory that everything has been formed out of nothing by a Creator?

A. The Buddha taught that two things are causeless, viz., Ākāsha, and Nirvāna. Everything has come out of Ākāsha, in obedience to a law of motion inherent in it, and, after a certain existence, passes away. Nothing ever came out of nothing. We do not believe in miracles; hence we deny creation, and cannot conceive of a creation of something out of nothing. Nothing organic is eternal. Everything is in a state of constant flux, and undergoing change and reformation, keeping up the continuity according to the law of evolution. ${ }^{15}$

Olcott's comparison between Buddhism's cosmogony and the laws of physics is in line with his efforts to help the religion with its transition into the modern era. More importantly, however, there is insistence that the cosmos is a continuous process, rather than a temporary arrangement with a set beginning or end. Even the next instance of Akasha is used in a way that implies a constant motion of events, rather than a static order of things:

363. Q. Does Buddhism teach the unchangeableness of the visible universe; our earth, the sun, the moon, the stars, the mineral, vegetable, animal and human kingdoms?

A. No. It teaches that all are constantly changing, and all must disappear in course of time. 364. Q. Never to reappear?

A. Not so: the principle of evolution, guided by Karma, individual and collective, will evolve another universe with its contents, as our universe was evolved out of the Ākāsha. ${ }^{16}$

\footnotetext{
${ }^{14}$ Henry Steele Olcott, A Buddhist Catechism According to the Canon of Southern Church, London: Trübner \& Co 1881, p. 58.

${ }^{15}$ Olcotт, A Buddhist Catechism, p. 74.

${ }^{16}$ Olсотт, A Buddhist Catechism, p. 80.
} 
By combining all of the above-mentioned statements, we get the concept of the Akashic Records as a place from which the universe was conceived, which also has an archival function for said universe. However, at the same time it would be premature to say that Olcott and his Catechism were the only possible factors behind the adoption of the Akashic Records. To consider the possibilities of other influences, a closer look at the state of contemporary sciences is required.

\section{Philosophy and physics in relation to the Akashic Records}

As mentioned previously, the idea of the Akashic Records did not originate from India, and therefore it is necessary look elsewhere for the influence behind it. Surprisingly, some of this influence might be found in places that one would not normally associate with the metaphysical: Physics.

To confirm that concepts similar to the Akashic Records already existed at the time, one might name the Scottish physicists Balfour Stewart (1828-1887) and Peter Guthrie (1831-1901) as prominent examples. Their work The Unseen Universe (1875) proposes an idea of an unseen space that exists aside from the visible universe. To quote:

Nevertheless, we do not hesitate likewise to assert that the visible universe must, certainly in transformable energy, and probably in matter, come to an end. We cannot escape from this conclusion. But the principle of Continuity, upon which all such arguments are based, still demanding a continuance of the universe, we are forced to believe that there is something beyond that which is visible, or, to use the words of an old writer (which we have inscribed on our title-page), "the things which are seen are temporal, but the things which are not seen are eternal." Looking back instead of forward - to the origin of this visible universe, rather than to its end, we are brought to a similar conclusion. If the visible universe is all that exists, then the first abrupt manifestation of it is as truly a break of continuity as its final overthrow. ${ }^{17}$

It must be noted that the two present their argument from a position that deems all existence has been created by a higher intelligence, as seen below:

Having thus classed our readers, they will now be anxious to learn our position. Let us begin by stating at once that we assume, as absolutely self-evident, the existence of a Deity who is the Creator of all things. "We are obliged," says Herbert Spencer in his First Principles, "to regard every phenomenon as a manifestation of some Power by which we are acted upon; though omnipresence is unthinkable, yet, as experience discloses no bounds to the diffusion of phenomena, we are unable to think of limits to the presence of this Power; while the criticisms of science teach us that this Power is incomprehensible."18

${ }^{17}$ Balfour Stewart, The Unseen Universe, London: Macmillan and Co.1875, p. 60.

${ }^{18}$ Stewart, The Unseen Universe, p. 43-44. 
This sentiment was repeated in a later part of the book, specifically when expressing the eternal continuity of existence. To give an excerpt:

We claim it as the heritage of intelligence that there shall be an endless vista, reaching from eternity to eternity, in each link of which we shall be led only from one form of the conditioned to another, never from the conditioned to the unconditioned or absolute, which would be to us no better than an impenetrable intellectual barrier.

It has also been seen that in this endless chain of conditioned existence we cannot be satisfied with a make-believe universe, or one- consisting only of dead matter, but prefer a living, intelligent universe, in other words, one fully conditioned. Finally, our argument has led us to regard the production of the visible universe as brought about by an intelligent agency residing in the unseen. ${ }^{19}$

Unfortunately, all this proves is that 19th century society possessed the concept of a separate dimension, which by itself would not suffice to define Akasha as it is known today. There is also the matter of their view of the universe which includes an active creating force behind its conception, which diverges from the more passive nature of the Akashic Records.

To truly understand the mindset that gave rise to the idea of a cosmic hub of information, it is important to examine the philosophical idea of determinism that dominated much of the scientific worldview up to the twentieth century.

Although there are many types of determinism, they share the common attributes of cause and effect. Simply put, there no event is motivated by chance; only by a sequence of set causes, which result in the given effect. So how does this tie in with the Akashic Records?

These cosmic archives themselves are a compendium of everything that has happened in the past, present, and future. Therefore, they operate under the notion that everything has a predestined path and that the world and everything in it will follow it, since if that were not the case, the entire idea of the Akashic Records would become obsolete.

Although determinism does not necessarily operate with the idea of predestination taken to such cosmic levels, a subsection of it did bring up the idea. This strict (or absolute) determinism was proposed primarily, if not exclusively, by Pierre Simon Laplace (1749-1827), most famously in the introduction to his Essai philosophique sur les probabilités, commonly known as Laplace's Demon:

We ought to then to regard the present state of the universe as the effect of its anterior state and as the cause of the one which to follow. Given for one instant an intelligence which could comprehend all the forces by which nature is animated and the respective situation of the beings who compose it - an intelligence sufficiently vast to submit these data to analysis - it would embrace in the same formula the movements of the greatest

19 Stewart, The Unseen Universe, p. 157. 
bodies of the universe and those of the lightest atom; for it, nothing would be uncertain and the future, as the past, would be present to its eyes. ${ }^{20}$

Simply put, Laplace proposes the idea of a super-intelligence that would be able to know all the forces and events transpiring in the world throughout both its history and future. ${ }^{21}$ In theory, such a mind would have absolute knowledge of the universe and its structure; a state of being not unlike the one that would grant access to the Akashic Records. Although there is no clear confirmation that Laplace's Demon served as an inspiration for the concept of the Akashic Records, the similarities between the two seem too notable to be a mere coincidence.

Later Theosophists also seemed to be aware of determinism and its influence on the Akashic Records. For example, Theosophy, Vol. 21 (no. 7, 1933) states the following:

Anyone able to see with a fair degree of accuracy all the causes which have been set in motion toward a certain end, can predict with an accuracy proportional to the scope of his vision. There is nothing mysterious about this; all of us carry it out through every hour of our lives - in fact, we could not live without doing it. ${ }^{22}$

There are however a few key questions that could potentially undermine this hypothesis: What about alternate futures? If one were to obtain insight into the knowledge contained in the records, would they also be able to perceive possible events and futures? Or would the existence of the records already imply a predetermined path for everything in existence?

To answer these questions, the state of contemporary physics needs to be observed. The quantum physics that operate with the notion of parallel universes first came about in 1956 thanks to Hugh Everett ${ }^{23}$ (although Erwin Schrödinger is credited with making the first known references to the concept several years earlier, in 1952) and only gained proper recognition much later. The fact that the Akashic Records came about in the late nineteenth century, more than fifty years prior to the first known theory of parallel universes, makes it rather obvious that in all probability, the Akashic Records were not imagined with this function in mind.

${ }^{20}$ Pierre Simon Laplace, A Philosophical Essay on Probabilities, translated by Frederick Wilson Truscott and Frederick Lincoln Emory, New York: Dover Publications 1951, p. 4.

21 "Laplace's Demon" [online], http://www.informationphilosopher.com, 2010, accessed February 2018, available online at http://www.informationphilosopher.com/freedom/laplaces_demon .html.

22 "Studies in Karma: Prevision, and Responsibility" [online], http://blavatsky.net/Wisdomworld /additional, 1933, accessed September 2019, available online at http://blavatsky.net/Wisdomworld /additional/StudiesInKarma-Series/Prevision-Destination.html.

${ }^{23}$ For more information see Hugh Everett, The Theory of Universal Wave Function, New Jersey: Princeton University 1956,140 p. 
Whether that remains to this day is another matter entirely, although admittedly one that is difficult to address, given the relative obscurity of the topic and the lack of material evidence pointing to a concrete answer.

There has been, however, a more recent effort towards marrying the physical and metaphysical once more. While more grounded in natural sciences than the original efforts of the Theosophical Society, it nonetheless acknowledges the possibility of the Akashic Records, as we will explain below.

\section{Possible influence of Christianity}

All of what has been said above ought to provide a clear understanding of the origin and influences behind the Akashic Records. However, before examining how these archives manifested in recent times, there is still one possible influence that should not be overlooked: Christianity.

It is worth noting that Christianity was the native religion of many prominent Western Theosophists. At the same time, many of them questioned their faith or outright rejected it. The aforementioned Olcott is a prominent example, though far from being the only one. To cite at least one example, a letter written in 1881 directly states:

Neither our philosophy nor ourselves believe in a God, least of all in one whose pronoun necessitates a capital H. Our philosophy falls under the definition of Hobbes. It is preeminently the science of effects by their causes and of causes by their effects, and since it is also the science of things deduced from first principle, as Bacon defines it, before we admit any such principle we must know it, and have no right to admit even its possibility. Your whole explanation is based upon one solitary admission made simply for argument's sake in October last. You were told that our knowledge was limited to this our solar system: ergo as philosophers who desired to remain worthy of the name we could not either deny or affirm the existence of what you termed a supreme, omnipotent, intelligent being of some sort beyond the limits of that solar system.

But if such an existence is not absolutely impossible, yet unless the uniformity of nature's law breaks at those limits we maintain that it is highly improbable. Nevertheless we deny most emphatically the position of agnosticism in this direction, and as regards the solar system. Our doctrine knows no compromises. It either affirms or denies, for it never teaches but that which it knows to be the truth. Therefore, we deny God both as philosophers and as Buddhists. We know there are planetary and other spiritual lives, and we know there is in our system no such thing as God, either personal or impersonal. Parabrahm is not a God, but absolute immutable law, and Iswar is the effect of Avidya and Maya, ignorance based upon the great delusion. The word "God" was invented to designate the unknown cause of those effects which man has either admired or dreaded without understanding them, and since we claim and that we are able to prove what we 
claim - i.e. the knowledge of that cause and causes we are in a position to maintain there is no God or Gods behind them. ${ }^{24}$

Nevertheless, given the sheer diversity of beliefs held by the members of the Theosophical Society, as well as the movement's tendency to claim religious figures (including personas such as Jesus Christ or Siddhartha Gautama) as part of their supposedly ancient teachings, it is plausible for the movement to have been influenced by elements of various established religions including Christianity. While Buddhism and Hinduism are the obvious choices, given their popularity in the movement, there is one more possible source of influence on the formation of the Akashic Records that needs to be examined: Namely, predestination.

It is true that both operate under different worldviews, but at the same time, their agreement that at least some things are firmly predetermined might lead some to ask about their possible similarities. First, a definition of predestination must be established.

Predestination is a Christian doctrine stating that God has eternally chosen those whom he intends to save. This choice does not cancel the free will of humanity, as that would negate the entire premise of the moral choice that is expected of the humankind. ${ }^{25}$

Although one might try to draw parallels, predestination is a concept sharply distinct from both determinism and fatalism, which do not necessarily involve the theistic concept of a personal deity making conscious choices. ${ }^{26}$ Determinism works by the notion that a cause in the present will result in a certain effect later on, but that is not how predestination views the world.

With predestination, the core principle is that not only does God have plans for the salvation of the world, but He also has an active role in the whole process, shaping and forming both events and people to bring such a plan to conclusion. This does not automatically imply divine determinism, or specifically that there is only possible future, the one God intentionally ordained, although these beliefs are not mutually exclusive. It is also important to note that there is more than one type of predestination. One need only compare Saint Augustine's single predestination where God only determined who would be saved, to John Calvin's double predestination, in which God has eternally set who will be saved and who will be damned. ${ }^{27}$

How would this compare with the notion of the Akashic Records? Within the scope of predestination, God is an active force that not only foretells events, but also

\footnotetext{
${ }^{24}$ A. T. BARker, "LETTER No. X" [online], http://www.phx-ult-lodge.org/mahatma_letters.htm\# No.\%20X\%201, accessed October2019, availableonlineathttp://www.phx-ult-lodge.org/mahatma _letters.htm.

25 Karl Rahner and Herbert Vorgmiller, Kleines theologisches Wörterbuch, Prague: Zvon 1996, p. 262.

26 "Predestination", in Lindsay Jones (ed.), Encyclopedia of Religion, vol. 5, 2nd ed., Michigan: Thomson Gale 2005, p. 3203.

${ }^{27}$ John Calvin, Concerning the eternal predestination of God, Louisville: Westminster John Knox Press 1997, p. 105-107.
} 
makes them happen. On the other hand, the Akashic Records were never even hinted to be anything other than a great compendium of all events present within the universe. To put it in other words, the main difference is that of an active force on one hand and a completely passive presence on the other.

The Theosophists themselves actively denied any connection with predestination in their works, despite the fact that their own version was not so different in its claim. As Gottfried de Purucker (1874-1942) put it during the Theosophical Forum of 1943:

So in answer to the question, Does Theosophy teach Predestination? The answer is an emphatic negative. No. But we do indeed teach destiny, which every man weaves for himself, around himself, and from which there is no escape, for it is the fruiting of the seeds sown by our own volition or choice. We do teach the doctrine, sublime and grand, as already stated, of man's free will, relatively so at least, dependent upon his evolutionary status, and of the inescapable Destiny that dogs the footsteps of the evil-doer, and showers blessings upon the doer of good. The one, retribution, is as inescapable as the other, compensation for the good that we have sown. ${ }^{28}$

As can be seen from the quote above, Theosophy denied teaching anything related to predestination, despite the fact that its focus on free will and its consequences was similar to the Christian doctrine in this particular regard. The main difference was that, within the theosophical view, the soul would be reincarnated, instead of heading for a final pre-determined destination. However, their common ground can be narrowed down to the fact that at least some events are already eternally destined to happen. To quote the aforementioned Theosophy:

For any event to happen at all, there must have been a definite moment when it became inevitable. ${ }^{29}$

Overall, while there does not seem to be much in the way of solid evidence for predestination influencing the idea of the Akashic Records, the fact that Theosophists needed to renounce the concept proves at least active knowledge or familiarity with the topic. The issue of Christian influence on Theosophy and its doctrines is a highly complex one, especially after the death of the movement's founders and the subsequent schism.

${ }^{28}$ Gottfired De Purucker, "Predestination” [online], https://www.theosociety.org/pasadena/ts /h_tsintro.htm, 1943, accessed July2019, availableonline athttps://www.theosociety.org/pasadena /forum/f21n04p161_predestination.htm.

29 "Studies in Karma: Prevision, and Responsibility", http://blavatsky.net/Wisdomworld/additional /StudiesInKarma-Series/Prevision-Destination.html. 


\section{Eternal continuation of existence within Akasha}

Ervin Lázsló (*1932) is a Hungarian philosopher and systems theorist. He is also a known proponent of the Quantum consciousness (additionally known as quantum mind) theory; a system of hypotheses proposing that quantum mechanical phenomena and superposition could contribute to forming the foundation of an explanation of consciousness.

More importantly, Lázsló presented an argument that the quantum vacuum (supposedly containing information on history from the Big Bang onward) itself is also a consciousness. To put it in simpler terms, everything in the universe has a consciousness, even at the level of sub-atomic particles. The state of the universe as it is known is therefore intentional instead of accidental. In such a view, this helps explain the sheer mathematical improbability of all existence possessing the form it has. As the philosopher put it:

Metaverse cosmologies have enormous explanatory potential. They can explain in principle how our universe came by the remarkable properties it actually has. Such an explanation is needed, because a universe such as ours - with galaxies and stars, and life on this and presumably other life-supporting planets - is not likely to have come about as a matter of serendipity. According to Roger Penrose's calculations, the probability of hitting on our universe by a random selection from among the alternative-universe possibilities is one in $10^{10123}$. This is an inconceivably large number, indicating an improbability of astronomical dimensions. Indeed, Penrose himself speaks of the birth of our universe as a "singularity" where the laws of physics do not hold. But if our particular universe is so staggeringly improbable, how did it come about? The explanation we can derive from Metaverse cosmologies is simple and powerful.

We know that the vacuum fluctuations that preceded the birth of our universe were precisely such that a life-bearing universe could come about. We also know that these fluctuations were not created by the primal explosion known as the Big Bang - that stupendous event only amplified them. The fluctuations that led to our staggeringly coherent universe were already present when our universe was born; they were there in its vacuum "prespace". ${ }^{30}$

In summary, the universe and everything contained within it are not a result of chance (as given the quote above, that would be extremely unlikely), but the result of an informed process. In addition, it is the A-field, also called the Akashic field, which serves as the information-carrying plane that observes not just the current universe, but also all those past and present (called the Metaverse within the book itself).

Prespace, in Lászlós interpretation, is the notion that the Big Bang started the universe, and the Big Crunch, which will happen when the universe goes into reverse

${ }^{30}$ ERvin Laszlo, Science and the Akashic Field: An Integral Theory of Everything, Rochester: Inner Traditions 2004, p. 68-69. 
and collapses back onto itself, is only a part of many cycles of universes just like ours appearing and disappearing, just like the subatomic particles in our world.

Lázsló believed that information could be transferred from one cycle to the next, which explains how the precise numbers for gravity, electromagnetism etc. came to be so exact when there has not been enough time for these to form randomly. These numbers are transferred from previous universes. ${ }^{31}$

It should come as no surprise that the Hindu view all of existence in a similarly cyclical way, even if the reasoning behind it is different. Yet it is here where Lázsló helps us bridge the gap between Indian philosophy and Western thinking, specifically by equating the quantum vacuum with the Akashic Records themselves. Within his work, he called them the A-field, a newly rediscovered information field of the universe:

Beyond the puzzle-filled world of the mainstream sciences, a new concept of the universe is emerging. The established concept is transcended; in its place comes a new/old concept: the informed universe, rooted in the rediscovery of ancient tradition's Akashic Field as the vacuum-based holofield. In this concept the universe is a highly integrated, coherent system, much like a living organism. Its crucial feature is information that is generated, conserved, and conveyed by and among all its parts. This feature is entirely fundamental. It transforms a universe that is blindly groping its way from one phase of its evolution to the next into a strongly interconnected system that builds on the information it has already generated. ${ }^{32}$

The A-field was meant to exist alongside other already known fields, namely the gravitational field (G-field), the electromagnetic field (EM-field), and the various nuclear and quantum fields. Instead of being metaphysical in its essence, the A-field was simply another natural part of the universe, one ever-present constant in the cosmic cycle of birth, death and rebirth.

This crossover between science and spiritual tradition has curious implications for the existence of the Akashic Records. Almost as if coming full circle back to the Theosophical Society and Helena Blavatsky, the option of gaining access to those universal archives has opened again. To quote Storoy's article once more:

Ervin Laszlo's theory says we are therefore linked to all people who have ever lived, and we can get access to them by accessing the Akashic field. This can explain life after death, because the past has never gone away, telling us that the past is ever present in everything we do. It clearly points to a universe where all is one and everything is linked. And if we tune ourselves into the Akashic field, we can access abilities that appear to be supernatural, but are in fact completely natural. Activities such as meditation can help us plug into

${ }^{31}$ DAvid Storoy, "Brain-heart" [online], https://www.scienceandnonduality.com, 2015, accessed March 2019, available online at https://www.scienceandnonduality.com/article/akashic-field -and-consciousness.

${ }^{32}$ Laszlo, Science and the Akashic Field, p. 112. 
the Akashic field and become much more than we are at present. Science and spirituality do not need to be set against each other as we have tended to think for so long. ${ }^{33}$

Despite the notable similarities to Blavatsky's work, there is not enough evidence to support the notion that the author derived his concepts from Theosophy and its teachings. Nevertheless, Laszlo is a prominent example of how concepts such as the Akashic Records were still kept alive even in the field of science throughout the 20th century.

\section{Conclusion}

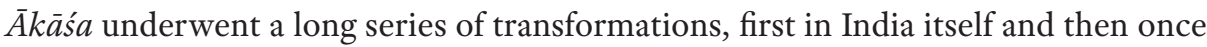
again under the influence of the Theosophical Society. By the time it became a part of the Western culture, the Akashic Records served as an intersection between quantum theory, metaphysical spirituality, and Indian-inspired philosophy.

However, it should also be said that absolutely no one was interested in every single layer that had been piled onto the concept of Ākāśa since 1875. The Theosophical Society, for example, was interested only in the metaphysical realm that could be viewed solely through the eyes of the few sufficiently advanced individuals like Helena Blavatsky in order to perform clairvoyance.

On the other side, there were scientists like Nikola Tesla (1856-1943), for whom $\bar{A} k a \bar{s}$ s was a theoretical possibility of advancement, especially in relation to matter and energy. It is also no secret that Tesla was an acquaintance of Swami Vivekananda, who in his teachings wished to reconcile modern science with Vedantic theories and cosmology. ${ }^{34}$

Unfortunately for Ākāśa, the same problems that originally plagued the Indian concept persisted even after its Western reimagining. There were numerous views on what the concept actually was, but absolutely no efforts were made to unify the diverse interpretations into a single meaning.

This inevitably resulted in the term eventually being abandoned by the scientific community and thus losing whatever was left of its connection to physical reality.

What is known as the Akashic Records is a metaphysical interpretation of Ākāśa, brought about by the influence of the Theosophical Society. Whether it was intended that way or not is impossible to say, but what is important to remember is that the form commonly known today is merely one of several variations an already ambiguous term took after it gained recognition. It may not be possible to discern its historical origin from modern fiction with absolute certainty, but at least the concept of

${ }^{33}$ STORoy, "Brain-heart" [online], https://www.scienceandnonduality.com/article/akashic-field -and-consciousness.

34 "Nikola Tesla and Swami Vivekananda" [online], Tesla Society, accessed January 2019, available online at http://www.teslasociety.com/tesla_and_swami.htm. 
the Akashic Records can always be used as a warning example about the dangers of loose interpretations.

\section{RefERENCES}

“Akashic record" [online], https://www.britannica.com, 2015, accessed January 2020, available online at https://www.britannica.com/topic/Akashic-record\#ref260257.

"Man Visible and Invisible" [online], Anand Gholap, 2016, accessed January 2020, available online at https://www.anandgholap.net/Man_Visible_And_Invisible-CWL.htm.

"Nikola Tesla and Swami Vivekananda" [online], Tesla Society, June 2008, accessed January 2019, available online at https://idoc.pub/documents/nikola-tesla-and-swami -vivekananda-j3no5y6j7x4d.

"Studies in Karma: Prevision, and Responsibility" [online], Blavatsky.net, 1933, accessed September 2019, available online at http://blavatsky.net/Wisdomworld/additional /StudiesInKarma-Series/Prevision-Destination.html.

BARKer, A. T., "LETTER No. X” [online], http://www.phx-ult-lodge.org/mahatma _letters.htm\#No.\%20X\%201, May 2008, accessed October 2019, available online at http://www.phx-ult-lodge.org/mahatma_letters.htm.

Blavatsky, Helena Petrovna, The Secret Doctrine - Volume 3, London: Theosophical Publishing Company 1888, 628 p.

Calvin, John, Concerning the eternal predestination of God, Louisville: Westminster John Knox Press 1997, 191 p.

Everett, Hugh, The Theory of Universal Wave Function, New Jersey: Princeton University $1956,140 \mathrm{p}$.

Gaukroger, Stephen, René Descartes: The World and Other Writings, Cambridge: Cambridge University Press 2004, 209 p.

Iannone, A. Pablo, Dictionary of World Philosophy, New York: Taylor \& Francis 2001, $554 \mathrm{p}$.

Jones, Lindsay (ed.), Encyclopedia of Religion, vol. 5, 2nd ed., Thomson Gale 2005, 3579 p.

Laplace, Pierre Simon, A Philosophical Essay on Probabilities, translated by Frederick Wilson Truscott and Frederick Lincoln Emory, New York: Dover Publications 1951, 196 p.

LASzlo, ERvin, Science and the Akashic Field: An Integral Theory of Everything, Rochester: Inner Traditions 2004, $205 \mathrm{p}$.

Nyanatusita, Bhikku, and Hellmuth Hecker, The Life of Nyanatolika Thera: The Biography of a Western Buddhist Pioneer, Kandy: Buddhist Publication Society 2008, $255 \mathrm{p}$.

Nyantiloka, Buddhist Dictionary, Kandy: Buddhist Publication Society 1998, 402 p.

Olcott, Henry Steele, A Buddhist Catechism According to the Canon of Southern Church, London: Trübner \& Co 1881, 106 p.

Pokazanyeva, Anna, "Mind Within Matter: Science, The Occult, and the (Meta)Physics of Ether and Akasha”, Zygon 51 (2, 2016): p. 318-346.

Shah, Pravin K. "Six Universal Substances or Entities” [online], Jain Study Center of North Carolina, 2002, accessed May 2019, available online at https://sites.fas.harvard .edu/ pluralsm/affiliates/jainism/jainedu/6dravya.htm.

Purucker, GotTFried De, "Predestination” [online], Theosociety.org, 1943, accessed July 2019, available online at https://www.theosociety.org/pasadena/forum/f21n04p161 _predestination.htm. 
Rahner, Karl, and Herbert Vorgrimler, Kleines theologisches Wörterbuch, Prague: Zvon 1996, $491 \mathrm{p}$.

Steiner, Rudolf, An Outline of Occult Science, London: Rudolf Steiner Press 1909, 205 p. Stewart, BALfour, The Unseen Universe, London: Macmillan and Co. 1875, 198 p.

Storoy, David, "Brain-Heart" [online], Science and Nonduality, February 2015, accessed March 2019, available online at https://www.scienceandnonduality.com/article /akashic-field-and-consciousness.

Vivekananda, Swami, Raja Yoga, Leeds: Celepha’s Press 2003, 297 p.

"Kosha" [online], Yogapedia.com, December 2007, accessed January 2020, available online at https://www.yogapedia.com/definition/5307/kosha. 